\title{
sciendo
}

\section{Towards an economic recovery after the COVID-19 pandemic: empirical study on electronic commerce adoption of small and medium enterprises in Vietnam}

\author{
Thuy Dam Luong HOANG \\ University of Economics and Business, Vietnam National University, Hanoi, Vietnam \\ luongthuyhd@vnu.edu.vn \\ Huy Khanh NGUYEN \\ University of Economics and Business, Vietnam National University, Hanoi, Vietnam \\ huynk@vnu.edu.vn \\ Ha Thu NGUYEN \\ University of Economics and Business, Vietnam National University, Hanoi, Vietnam \\ hant@vnu.edu.vn
}

\begin{abstract}
The COVID-19 outbreak has created a severe crisis for general economic situation. Despite the short time span of the pandemic, many innovations are implemented for organizational survival and recovery in the competitive market environment of digital age. This paper aims to find out significant factors and how they impact on E-commerce adoption of small and medium enterprises in Vietnam, especially in the epidemic time. The results reveal that technology perceived compatibility has the greatest effect on E-commerce adoption, followed by management support and external pressure. Moreover, external support only has minor impact on E-commerce adoption in the Covid-19. Meaningfully, this study makes contribution to both innovation literature and practical management with new insight of current Vietnamese situation for small and medium organizations.
\end{abstract}

Keywords: E-commerce adoption, innovation, TOE framework, small and medium enterprises, COVID-19pandemic.

Please cite the article as follows: Hoang, T. D., Nguyen, H.K., Nguyen, H. T. (2021), "Towards an economic recovery after the COVID-19 pandemic: empirical study on electronic commerce adoption of small and medium enterprises in Vietnam", Management \& Marketing. Challenges for the Knowledge Society, Vol. 16, No. 1, pp. 47-68, DOI: 10.2478/mmcks-2021-0004.

\section{Introduction}

COVID-19 pandemic is considered to be the notorious economic shock arising throughout the year 2020. International and domestic lockdowns, national treasure declines, commercial business stagnancies have been globally mentioned since March when the pandemic began to spread. The worldwide economy gets under depressed situation and another crisis which is more serious than the 2008 financial slump has emerged. The impact

DOI: $10.2478 / m m c k s-2021-0004$ 
of COVID-19 can be noticeable in business area whereas the interaction and face-to-face negotiations have yet been allowable (Farmaki et al., 2020). As predictions indicated, it is not until the year 2025 may the global economy recover to the ideal situation as it was in 2019. Therefore, although the negative effects of the deadly pandemic are still presented currently, the commercial recovery phase must be projected to start due to the fact that economic development has plummeted to historic bottom (Gourinchas et al., 2020). Particularly, small and medium enterprises (SMEs) category is among the mostly-affected enterprises because the category includes weakly and averagely potential power (Syriopoulos, 2020). Therefore, the recovery phase of SMEs has to be initial stage sooner than ever.

In this study, the authors concentrate on determining the effects of COVID-19 crisis on business failure, specifically on SMEs and providing measurements for recovery phase. As the spread of COVID-19 pandemic and the interdependence of the global economy increases the business uncertainty, predicting the future seems an impossible task. Consequently, SMEs encounter difficulties in solving the recovery several problems. Firstly, SMEs are vulnerable to financial risks due to its remarkable dependence on leverage finance with numerous debts from banks, intermediaries or other financial supporters (Gourinchas et al., 2020). Therefore, under the impact of COVID-19 pandemic, the money issues become worse and SMEs development is typically hindered. As a result, SMEs are unable to service their clientele, to pay salary to their employees and be compliant to their commitment with their suppliers (Syriopoulos, 2020). More importantly, the operations of SMEs are subjected to disruption in demand side and supply side (Juergensen et al., 2020). The corona virus spreads the world and leads to the fact that the demand for products from SMEs in particular and other category of enterprises in general, decline sharply in the period (Priyono et al., 2020). On the other sides, supply of inputs for SMEs encountered logistical problems due to lockdowns and isolation (Juergensen et al., 2020). Therefore, it negatively creates shortage in several inputs, namely: transportation, product input or labour.

Nevertheless, whether how bad the crisis becomes, SMEs have to be focused on the recovery phase to minimize the losses afterwards. Generally, coronavirus-related pandemic has strong effects on SMEs and forced thousands of SMEs to be failed in the market. Therefore, it is necessary for SMEs to find the fastest ways to bounce back after downward trend throughout the year 2020. E-commerce is proven to be one of the most effective measure to overcome dis-continued operations during the COVID-19 pandemic (Gao et al., 2020). In order to minimize the infected, human-to-human transmission must be prevented and virtual platform created by technology should be enhanced. Sellers are still able to find buyers online and provide the service with the help of specially-assisted logistics. Moreover, it is believed that digital technology enables firms to transform business models quickly (Dinca et al., 2019), and not in traditional or linear ways (Priyono et al., 2020). Products or service are presented online and it is more visual than traditional manner. E-commerce, as a result, creates the chance of widely customer-served and increase the sales volume for a typical SME. In other words, buyer behaviours have changed and E-commerce becomes leading trend in market during the coronavirus-related epidemic. Therefore, it is the online shopping that reshape the economy for SMEs after COVID-19 and the virtual platforms would provide potential recovery opportunities for not only SMEs but also global economy.

Consequently, the aim of this research is to (1) identify related technological, organizational, environmental and managerial factors in e-business and (2) test the moderating effect of these factors on Vietnamese SMEs E-commerce adoption. The next 
section is about literature review analyses of related papers, followed by a part of data result. Finally, this article concludes with finding discussion and future implication. Due to consistent time period and unprecedented phenomena like COVID-19, although the study produces several limitations, significant recommendations for the recovery phase of SMEs are still proposed. Besides, the study looks at the problem from SMEs point of view, therefore, it would be no policy-related and completely for measurement that SMEs can implement for recovering after COVID-19 pandemics. The results are acknowledged by the authors and do not violate any economic regulations.

\section{Literature review}

\section{E-commerce adoption}

Electronic-commerce, by definition refers as a particular component of e-business relating to the Internet contribution in terms of sale, display, information-providing, money transfer and delivery support (Kwilinski et al., 2019). More particularly, online shopping relates closely to the sharing of business information, maintaining business relationships, and conducting business transactions by means of telecommunications networks (Scupola et al., 2009). In other words, the internet contributes greatly to the operation of e-commerce. The online business-to-consumer (B2C) transactions have been recognized as one of the major technological innovations altering market channels in this information age (To and Ngai, 2006). With the help of internet development, the distance between businesses and customers is narrowed and even eliminated. A person can access a large number of products online via a portable device or a laptop. The other potential benefit of adopting state-of-theart technologies for SMEs is to enhance the digitization of internal operations and processes, improving performance effectiveness and efficiencies, re-engineering business models, and ensuring business survival (Kwilinski et al., 2019). Information technologies are used to increase sales, business efficiency and create a base for new products and services in an Ecommerce process (Dima \& Maassen, 2018). Depending on particular activities, each company communicates with many other subjects, which can include both private or corporate clients, and business partners, suppliers (Rodgers and Harris, 2003). In other words, e-commerce is becoming more vital for business in the modern economy and online shopping seems gradually popular nowadays, in which people can handle the purchase within several minutes and much higher productivity than physical shopping (Hui et al., 2013). Besides, with the help of the internet, sellers can place promotional deals online which are rather quick to spread in the buying forces. Moreover, online shopping is becoming more protected as more security policies are being enforced by many online marketplaces. Generally, it is beneficial for business to move the concentration to online shopping in the changing economy, especially after the COVID-19 pandemic when people are heading online more often. However, the adoption of e-commerce encounters numerous problems.

With regards to small and medium scale enterprises (SMEs), many challenges continue to hinder digital technology adoptionm, especially in developing economies (Akpan et al., 2020). The shortage of resources is the extreme weakness of SMEs; therefore, the allocation should be reasonable and focused on important features. More importantly, the SMEs' inability to deploy cutting-edge technologies is barely possible due to the financial issue (Akpan et al., 2020). Therefore, technologies such as virtual reality and cloud computing for

remote operations and non-digitization of business activities may not be targeted. According 
to Rahayu and Day (2015), the adoption of e-commerce by SMEs, especially in developing countries, is still very far behind the adoption by large companies. Besides, Dubelaar et al. (2005) pointed out nine determinants preventing SMEs's E-commerce adoption, namely: the lack of human resources; internal resistance; unready customers; lack of support; security issues; unready business partners; internal constraints; a lack of IT resources and lack of support. Hence, there tends to be a lack of success stories, not having knowledge in ecommerce and lack of information about the potential impact of e-commerce implementation on business performance of SMEs. Generally, even though SMEs are increasingly adopting e-commerce, their use and exploitation is still limited and small companies have a limited understanding of its potential (Scupola, 2009).

\section{Theoretical Foundation in E-commerce Adoption research}

The Technology-Organization-Environment (TOE) framework is initially developed by Tornatzky et al. (1990) that illustrates the impact of external and internal factors in adopting a new type of innovation. There are three aspects in this model, including technology aspect, organization aspect and other external aspects (such as environment context) (Rahayu and Day, 2015). Particularly, technological context involves internal and external characteristics of technology of a company, whereas organizational aspect refers to the nature, resources or managerial structure of the firm (Rahayu and Day, 2015). Besides, the environment context is about external factors influencing firm operations such as competitors, suppliers and government policies (Zhu et al., 2006).

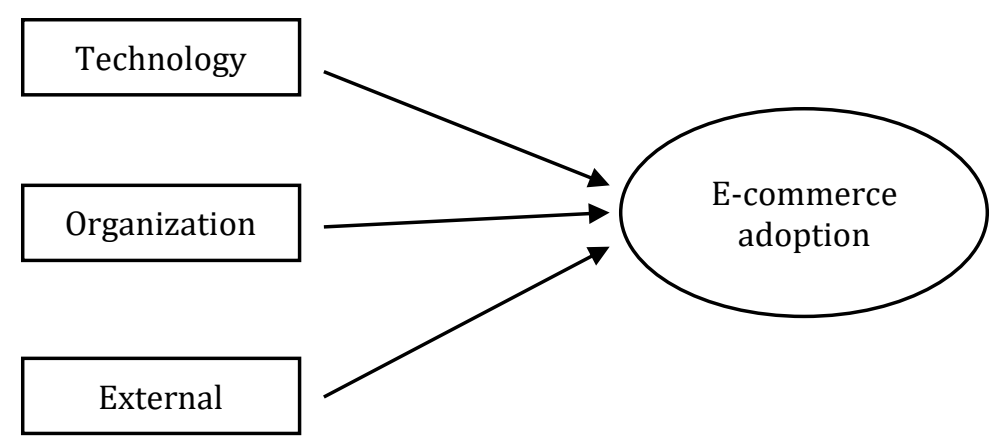

Figure 1: The TOE framework for E-commerce adoption

Source: Authors' own research.

In the context of e-commerce implementation, many prior researches mainly considered TOE framework as the theoretical basis for the research model because of two key reasons (Rahayu and Day, 2015; Mohtaramzadeh et al., 2017). First, TOE has been widely recognized as a well-established framework in the context of technology application in an organization (Ramdani et al., 2013; Chiu et al., 2017). Second, not only technological issue, but TOE framework also covers micro and macro variables such as organizational and environment factors (Hameed et al., 2012). Therefore, TOE has more explanatory and applied power in research as well as managerial implication. Due to major points, it is believed that TOE can explain IT innovation adoption in firm comprehensively. Nevertheless, there are still several gaps addressed to this theory, in which individual characteristic of managers or staffs in company is core factor that is ignored in the model (Ghobakhloo and 
Tang, 2013). On the other hand, in practice, it is attributed that managers or the characteristics of manager of a firm also have significant impact on technological implication, which is well documented in researches of Rowe et al. (2012), Mohtaramzadeh et al. (2017) or Chiu et al. (2017). Therefore, in the case of e-commerce adoption in Vietnam small and medium enterprises, technological, organizational, environmental and individual context are taken into account as main factors.

Table 1: Summary of the factors for E-commerce application in SMEs

\begin{tabular}{|c|c|c|}
\hline Authors & Main context & Main factors \\
\hline Abed (2020) & $\begin{array}{l}\text { (1) Technological context } \\
\text { (2) Organizational context } \\
\text { (3) Environmental context }\end{array}$ & $\begin{array}{l}\text { (1) Perceived usefulness, security concern } \\
\text { (2) Management support, organizational readiness } \\
\text { (3) Consumer pressure, trading partner pressure }\end{array}$ \\
\hline $\begin{array}{c}\text { Hamad et al. } \\
\text { (2018), Ocloo et al. } \\
\text { (2018) }\end{array}$ & $\begin{array}{l}\text { (1) Technological factor } \\
\text { (2) Organization factor } \\
\text { (3) Environment factor }\end{array}$ & $\begin{array}{l}\text { (1) Relative advantage, compatibility, complexity } \\
\text { (2) Management support, firm size } \\
\text { (3) Competitive pressure, business partner pressure, } \\
\text { Government support }\end{array}$ \\
\hline Chiu et al. (2017) & $\begin{array}{l}\text { (1) Technology context } \\
\text { (2) Organizational context } \\
\text { (3) Environment context }\end{array}$ & $\begin{array}{l}\text { (1) relative advantage, compatibility, complexity, } \\
\text { trialability, observability } \\
\text { (2) information intensity, management support, } \\
\text { employee's knowledge, absorptive capability } \\
\text { (3) competitive pressure, business partner, external } \\
\text { supports, government supports }\end{array}$ \\
\hline $\begin{array}{c}\text { Mohtaramzadeh et } \\
\text { al. (2017) }\end{array}$ & $\begin{array}{l}\text { (1) Technological factors } \\
\text { (2) Organizational factors } \\
\text { (3) Environmental factors } \\
\text { (4) Organizational culture }\end{array}$ & $\begin{array}{l}\text { (1) technology benefits, cost of adoption } \\
\text { (2) top management support, infrastructure and } \\
\text { capabilities } \\
\text { (3) competitive pressure, partner pressure, legal } \\
\text { infrastructure, government support } \\
\text { (4) Organizational culture }\end{array}$ \\
\hline $\begin{array}{l}\text { Rahayu and Day } \\
\text { (2015) }\end{array}$ & $\begin{array}{l}\text { (1) Organizational context } \\
\text { (2) Technological context } \\
\text { (3) Environmental context } \\
\text { (4) Individual context }\end{array}$ & $\begin{array}{l}\text { (1) Technology readiness, firm size } \\
\text { (2) Perceived benefits, perceived compatibility, cost } \\
\text { (3) Customers pressure, competitor pressure, } \\
\text { external support } \\
\text { (4) Owners innovativeness, owners IT ability, owners } \\
\text { IT experience }\end{array}$ \\
\hline $\begin{array}{l}\text { Bakri and } \\
\text { Katsioloudes } \\
\text { (2015) }\end{array}$ & $\begin{array}{l}\text { (1) External organizational } \\
\text { factors } \\
\text { (2) Internal organization } \\
\text { factors } \\
\text { (3) SMEs manager's } \\
\text { perceptions. }\end{array}$ & $\begin{array}{l}\text { (1) the readiness, external pressure } \\
\text { (2) SMEs strategic, perception of SMEs's managers } \\
\text { (3) Manager's perceptions. }\end{array}$ \\
\hline $\begin{array}{l}\text { Ghobakhloo and } \\
\text { Tang (2013) }\end{array}$ & $\begin{array}{l}\text { (1) Perceived benefits, (2) } \\
\text { perceived compatibility, ( } 3 \text { ) } \\
\text { perceived cost, (4) perceived } \\
\text { risks, (5) computer } \\
\text { knowledge, }(6) \\
\text { innovativeness }\end{array}$ & $\begin{array}{l}\text { (1) Perceived benefits, (2) perceived compatibility, } \\
\text { (3) perceived cost, (4) perceived risks, (5) computer } \\
\text { knowledge, (6) innovativeness }\end{array}$ \\
\hline
\end{tabular}

Source: Authors' own research. 


\section{Factors affecting E-commerce adoption in Vietnam SMEs}

Organizational context

The organizational context involves in firm characteristics that have significant impact on the adoption of e-commerce, such as staff knowledge, firm size, firm resources, strategic orientation, or technology readiness, etc...Regard to employees of small and medium enterprises, many prior researches state that internal expertise of SMEs can be considered as one of the main reasons in deciding whether to accept new technology or not, which play a key role in adopting E-commerce (Teo and Tan, 1998; Rowe et al., 2012). In practice, a number of organizations cannot attempt to do innovation in business context because their staffs do not have enough skills and knowledge of E-commerce or technology (Rowe et al., 2012). Besides, Rahayu and Day (2015) also support these abovementioned viewpoints when reveals that the ability to provide human resources relates to company intention to implement E-commerce. The more skilled workers SMEs have, the more likely E-commerce adoption is. Thus, the first hypothesis is that:

H1: Organization employees positively influence the adoption of E-commerce by Vietnamese SME

Another important factors in organizational context are readiness, which have been researched in several papers, such as Iacovou et al. (1995), Bakri and Katsioloudes (2015) or Rahayu and Day (2015). Enterprise readiness includes financial and technological resources that are remarkably essential to approve new innovation (Bakri and Katsioloudes, 2015). To be specific, financial readiness is the availability to pay for new technology, modern equipment or update system; while technological readiness involves in the level of IT usage and management in business environment (Iacovou et al., 1995). In other words, Bakri and Katsioloudes (2015) notes that if a company has a low level of computerization, it will be especially sophisticated for them to adopt E-commerce or any kind of innovation technology. Furthermore, organizational readiness also refers to strategic orientation, meaning that when a firm has a proposed strategy plans about adopting new technology, it might be implemented closely based on that (Hong and Zhu, 2006; Requena et al., 2007). Consequent, organizational readiness helps speed up the E-commerce adoption process. The hypothesis is proposed as below:

H2: Organizational readiness positively influence the adoption of E-commerce by Vietnamese SMEs

Technology context

The technology context is about those aspects related to technological operation in ecommerce, such as benefit, compatibility, complexity or event risks (Tiago and Maria, 2010). Firstly, perceived benefits are defined as the degree of advantage a new technology can bring to a firm (Jabri and Sohail, 2012). In reality, firms will not accept a technology if it does not bring any advantages or help to develop business opportunities (Duan et al., 2012). The greater the perceived benefit is, the more possibly a firm will adopt this technology. Especially in competitive and hard environment such as COVID-19pandemic, these benefits bring more motivation for company to adopt E-commerce system. Hence, the next hypothesis is stated that:

H3: Technology perceived benefits positively influence the adoption of E-commerce by Vietnamese SMEs 
Secondly, compatibility is another factor having great impact on E-commerce adoption of SMEs (Morteza et al., 2011). Compatibility is about whether this technology is appropriate with company structure, value, object or other external aspects (Morteza et al., 2011). Particularly, an enterprise only chooses an innovation if it meets the need of organization as well as conforms certain its internal and external values, which enable to reduce risks and easily implement during process (Rahayu and Day, 2015). Conversely, it is found that the incompatibility between E-commerce and business picture hesitates company intention to accept new technology and negatively influence on worker attitudes (Rowe et al., 2012). Such that, hypothesis 4 is suggested as:

H4: Technology perceived compatibility positively influence the adoption of E-commerce by Vietnamese SMES

\section{Environmental context}

Among environmental characteristics, two main aspects relate to external pressure and external support that impact on e-commerce adoption (Rahayu and Day, 2015). In this study, the external pressure refers to competitors' competitiveness, customers' requirement and especially, the major influence of COVID-19pandemic. In fact, the coronavirus disease pandemic has created extraordinary challenges for worldwide business when Government implements social distancing programs and travel restrictions, almost business experience both demand and supply shocks (Chang and Meyerhoefer, 2020; WHO, 2020). Consequently, face-to-face transaction is reduced and online trading is increased sharply in economy and society (Dannenberg et al., 2020). Along with it, due to the suddenly expansion of online business, there is a special competitiveness among companies. Customers, thus, also require higher quality products as well as better services (Chang and Meyerhoefer, 2020). In many cases, these objects bring positive power to pressure an SME to adopt a new particular kind of technology. The higher level of competition within the industry, the greater e-commerce can be achieved (Zhu and Kraemer, 2006). The next hypothesis is proposed: SMES

H5: External pressure positively influence the adoption of E-commerce by Vietnamese

In addition to pressure, support from external parties such as Government, communities or even other businesses is also considered as one of significant factor having influence on e-commerce adoption by SMEs (Rahayu and Day, 2015). It is common knowledge that small and medium companies has lack of resources like financial, technological and human resources; hence, they are always in need of support from others. For example, financial policies from Government to protect these companies during the COVID-19pandemic, or a support from IT vendor to learn and adopt new technology. Hence, these explanations result in the following hypothesis:

H6: External support positively influence the adoption of E-commerce by Vietnamese SMES

\section{Management support}

Although it is not mentioned in TOE framework, many researches focus on the importance of individual context or management support in adopting E-commerce in SMEs, especially in developing countries (Rahayu and Day, 2015; Mohtaramzadeh et al., 2017). Specifically, owner/managers' knowledge is another trait having impact on e-commerce adoption because users' skill and knowledge towards technology can result in seeking, trying or 
accepting new innovation (Ghobakhloo and Tang, 2013). Obviously, a manager who is good at technology, tends to seek solutions by changing business or supports innovation is usually considered as an innovative manager (Thong and Yap, 1995). Moreover, the research of Thi and Eam (2011) is also in line with the abovementioned result that top management has significantly support e-business. However, if manager prefers to adopt innovation, they have to face up with a number of obstacles or risks. As a technology innovation, e-commerce implementation is extremely risky, especially in the case of small business in developing countries (Ghobakhloo and Tang, 2013). Therefore, managers should be well educated on the functions, implementations and benefits of E-commerce applications for their business. The hypothesis is presented as below:

H7: Management support positively influence the adoption of E-commerce by Vietnamese SMEs

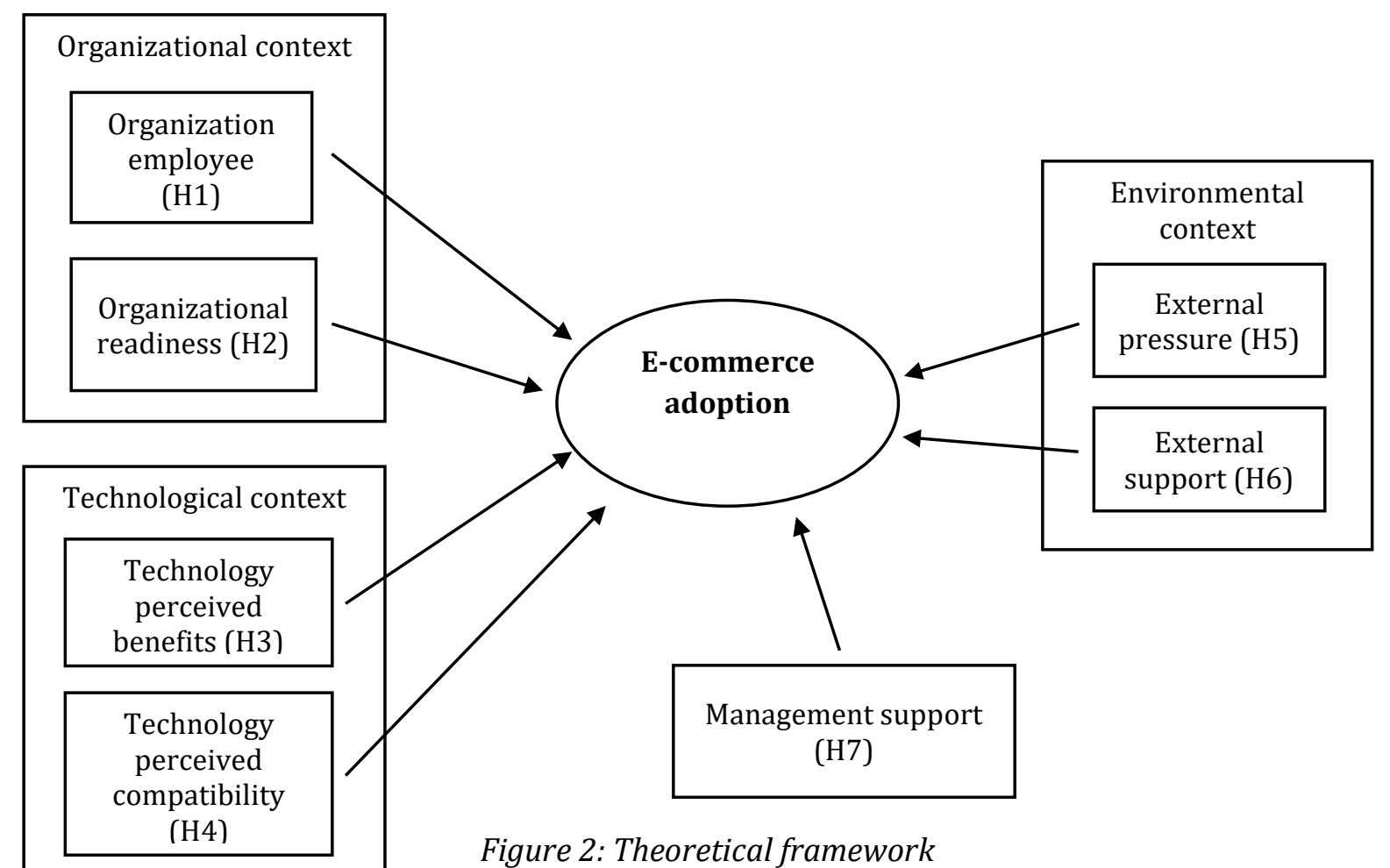

Source: Authors' own research

\section{Methodology}

\section{Sampling method}

With a view to finding out the real situation of E-commerce adoption in Vietnamese small and medium enterprises during the COVID-19 pandemic, a questionnaire is proposed in order to collect opinions of small and medium enterprises in Vietnam towards E-commerce adoption during and after the COVID-19 pandemic. To be specific, target respondents for this study is owners/managers, leaders of staff in Vietnamese SMEs (the company has less than 100 employees). This purposive sampling criterion is set to eliminate firms having not enough experiences in adapting E-commerce. Therefore, a data collection process is carried out by launching both online and offline survey from November 2020 to December 2020, in 
which Vietnamese social media sites (such as Facebook, Gmail, Google Drive) are remarkably important to approach target respondents. The sample is selected based on convenient samplings and taken into account the balance of age, gender, education level and company field in order to maximize the number of participants towards this topic.

\section{Sample size}

In quantitative analysis, sample size depends on the number of variables. According to Hair et al. (2013), the number of observations is required to be at least 5 times higher than the number of question items. In this study, the number of items is 32 , so that the minimum required sample size should be 160 observations. In order to ensure the reliability of research result, 250 surveys are distributed but only 229 surveys are qualified. This number of respondents meets sample size requirement; therefore, it can be used for quantitative analysis (Hair et al., 2013)

\section{Measurement and methodology}

The theoretical framework is adapted from extended TOE framework and then a questionnaire is built upon this framework. Particularly, these indicators are also used by Rowe et al. (2012) and Mohtaramzadeh et al. (2017). The final questionnaire includes 32 items divided into two parts. The first part of questionnaire includes all factors having impact on E-commerce adoption of SMEs, while the second part is about customers' demographic information. In order to avoid questionnaire fatigue and comprehensive errors, all experience statement in part 1 are positively worded (Buttle, 1996). All of the measures in study employ a 5-point Likert scale. Valid data is analysed through the following steps: (i) Descriptive statistics, (ii) Reliability and validity test, (iii) Exploratory factor analysis, and (iv) Multiple regression analysis.

\section{Research results}

\section{Descriptive analysis}

The statistical results described in table 1 show:

- In regards to respondents, 59.8\% of them are male and belongs to the group of 20-29 years old, which is understandable because in Asian, male is likely to be an organizational manager and the age of 20-29 tends to update new technology easily. Moreover, half of participants have bachelor degrees. However, not only manager, this survey also asks for opinions of senior staffs and team leaders because these people have enough knowledge, skill as well as working time to understand company situation.

- In term of company, nearly a half of companies are retail/wholesale, followed by manufacturing firms and then other company types. Almost of them is placed in mega cities such as Hanoi, Ho Chi Minh, Danang, etc.

Table 2: Overall respondent's demographic

\begin{tabular}{|l|l|l|l|l|l|}
\hline & Frequency & Percent \% & & Frequency & Percent \% \\
\hline Gender & & & Education & & \\
\hline Female & 82 & 35.8 & Bachelor & 127 & 49.0 \\
\hline Male & 137 & 59.8 & Master & 91 & 35.1 \\
\hline Prefer not to say & 10 & 4.4 & Other & 11 & 4.2 \\
\hline
\end{tabular}




\begin{tabular}{|l|l|l|l|l|l|}
\hline Age & & & Service type & & \\
\hline $20-29$ & 153 & 66.8 & Manufacturing & 85 & 32.8 \\
\hline $30-39$ & 71 & 31 & Retail/Wholesale & 120 & 46.3 \\
\hline $40-49$ & 5 & 2.2 & Other & 24 & 9.2 \\
\hline Position & & & Experience & & \\
\hline Senior staff & 43 & 18.8 & About 1 year & 63 & 27.5 \\
\hline Team leader & 94 & 41.0 & About 2 to 3 years & 82 & 35.8 \\
\hline Manager & 92 & 40.2 & Over 3 years & 57 & 24.9 \\
\hline Area & & & Not yet & 27 & 11.8 \\
\hline Mega cities & 222 & 97 & & & \\
\hline Other cities & 7 & 3 & & & \\
\hline
\end{tabular}

Source: Authors' own research

\section{Reliability test}

According to the result of reliability test, it is recognized that the mean for most constructs of framework is from 3 to 4, which shows the medium compliance of SMEs with these statements. Especially, item EP2 (Vietnamese customers requires a better quality of transaction platform), EP3 (COVID-19 pandemic leads to the raise of E-commerce adoption in almost enterprises) have mean value of 4.28 and 4.02 respectively, and item TC5 (TC5Ecommerce adoption is compatible with customer's behaviour during Covid-19) has mean value of 4.07, which means that most Vietnamese SMEs adapt E-commerce is due to COVID19 pandemic (appendix 2).

Besides, all items have high Cronbach's alpha (over 0.7) and high coefficient of item-tototal correlation $(0.5-0.8)$, which suggest the high correlating of these items and confirm the consistency of the measurement variables (appendix 2). With these results, these factors of E-commerce adoption are mostly reliable and suitable for next analyses.

\section{Exploratory factor analysis}

Table 3: KMO and Bartlett's Test Result

\begin{tabular}{|l|l|l|}
\hline \multicolumn{2}{|l|}{ Kaiser-Meyer-Olkin Measure of Sampling } & .822 \\
\hline \multirow{3}{*}{ Bartlett's Test of Sphericity } & Approx. Chi-square & 4904.733 \\
\cline { 2 - 3 } & Df & 253 \\
\cline { 2 - 3 } & Sig. & 0.000 \\
\hline
\end{tabular}

In general, the KMO measure of 0.822 being higher than the minimum level of 0.5 is considered as marvellous statistics (table 2). Moreover, the significance of Bartlett's test of Sphericity is 0.000 . As a result, the dataset is appropriate for factor analysis.

In term of exploratory factor analysis, the ideal factor loading is 0.4 because this test has 229 samples (Hair et al., 2013). After running initial step of factor analysis with the use of varimax rotation, 25 items are summarized to eight underlying factors. However, item OE3 and $0 R 5$ had cross factor loading below 0.4 meaning that these variables are removed from the scale. When running final factor analysis, 23 items are stayed in 8 underlying factors and all items are strongly loaded in particular factors, meeting the requirements of convergent and discriminant validity (Cohen et al., 1992). 
Table 4: Rotated Component Matrix for final step

\begin{tabular}{|l|l|l|l|l|r|r|r|r|}
\hline & \multicolumn{9}{|c|}{ Component } \\
\cline { 2 - 9 } & 1 & 2 & 3 & 4 & 5 & 6 & 7 & 8 \\
\hline OE1 & & & & & & .718 & & \\
\hline OE2 & & & & & & .816 & & \\
\hline OR4 & & & & & & & .408 & \\
\hline OR6 & & & & & & & .559 & \\
\hline OR7 & & & & & & & .885 & \\
\hline TB1 & .650 & & & & & & & \\
\hline TB2 & .648 & & & & & & & \\
\hline TB3 & .811 & & & & & & & \\
\hline TC4 & & & .688 & & & & & \\
\hline TC5 & & & .438 & & & & & \\
\hline TC6 & & & .719 & & & & & \\
\hline EP1 & & & & .464 & & & & \\
\hline EP2 & & & & .814 & & & & \\
\hline EP3 & & & & .746 & & & & \\
\hline ES4 & & & & & .908 & & & \\
\hline ES5 & & & & & .758 & & & \\
\hline ES6 & & & & & .692 & & & \\
\hline MS1 & & .665 & & & & & & \\
\hline MS2 & & .615 & & & & & & \\
\hline MS3 & & .734 & & & & & & \\
\hline EA1 & & & & & & & & .707 \\
\hline EA2 & & & & & & & & \\
\hline EA3 & & & & & & & & .747 \\
\hline
\end{tabular}

Source: Authors' own research

\section{Regression analysis}

Pearson Correlations

Table 5: Pearson Correlation among independent and dependent variables

\begin{tabular}{|l|l|l|l|l|l|l|l|l|l|}
\hline & & OE & OR & TB & TC & EP & ES & MS & EA \\
\hline EA & Pearson & 0.515 & 0.551 & 0.598 & 0.680 & 0.488 & 0.438 & 0.667 & 1 \\
\hline & Sig & 0.000 & 0.000 & 0.000 & 0.000 & 0.000 & 0.000 & 0.000 & 0.000 \\
\hline
\end{tabular}

Note: Correlation is all significant at the 0.01 level (2-tailed)

The Pearson Correlation result of this paper indicates that all variables are positively correlated to E-commerce adoption in Vietnamese small and medium enterprises. Particularly, the value of all correlation is smaller than 0.8 ; thus, there is no multicollinearity among the independent variables (Gujarati, 2004). 
Regression model

Table 6: Regression model result

\begin{tabular}{|l|l|l|l|}
\hline & $\begin{array}{l}\text { Standardized } \\
\text { Coefficients Beta }\end{array}$ & Sig. & VIF \\
\hline Organizational employee (OE) & 0.101 & 0.085 & 1.892 \\
\hline Organizational readiness (OR) & 0.030 & 0.654 & 2.561 \\
\hline Technology perceived benefit (TB) & 0.016 & 0.849 & 3.983 \\
\hline Technology perceived compatibility (TC) & 0.443 & 0.000 & 2.732 \\
\hline External pressure (EP) & 0.245 & 0.001 & 2.809 \\
\hline External support (ES) & 0.187 & 0.000 & 1.408 \\
\hline Management support (MS) & 0.395 & 0.000 & 2.756 \\
\hline R & 0.778 & & \\
\hline R Square & 0.605 & & \\
\hline Adjusted R square & 0.593 & \\
\hline Model Significance & 0.000 & \\
\hline
\end{tabular}

Source: Authors' own research

Overall, the $R$ value is 0.778 revealing a high degree of correlation. The value of adjusted $R$ square is 0.605 , hence, it can be concluded that E-commerce adoption in Vietnamese SMEs can be explained by $60.5 \%$ of technological, organizational, environmental context and management support. In addition, with the significant value is 0.000 (lower than 0.05 ), this model is meaningful enough in predicting the outcome variables.

Regards to independent factors, the coefficient of technology perceived compatibility, external pressure, external support and management support are significant at $\mathrm{p}$-values lower than 0.05 , at $0.000,0.001,0.000$ and 0.000 respectively. Furthermore, values of the standardized coefficient of four abovementioned factors are $0.443,0.245,0.187$ and 0.395 respectively. In other words, the p-values of organizational employee, organizational readiness and technology perceived benefit are all over than 0.05 , meaning that these factors have no significant impact on Vietnamese E-commerce adoption.

As discussed above, it can be concluded that Hypothesis 4, Hypothesis 5, Hypothesis 6 and Hypothesis 7 are supported; while Hypothesis 1, Hypothesis 2 and Hypothesis 3 are rejected. Consequently, the findings confirm the literature that, improvements in four aspects (technology perceived compatibility, external pressure, external support and management support) can be positively beneficial to implementation of E-commerce in Vietnam SMEs during the COVID-19 pandemic. The ratio of each independent factors is shown in table 7.

Table 7: The order of influence level

\begin{tabular}{|l|l|l|l|}
\hline \multicolumn{1}{|c|}{ Factor } & \multicolumn{1}{|c|}{ Beta } & \multicolumn{1}{|c|}{$\begin{array}{c}\text { The influence } \\
\text { percentage }\end{array}$} & $\begin{array}{c}\text { The order of } \\
\text { influence level }\end{array}$ \\
\hline Technology perceived compatibility (TC) & 0.443 & 34.9 & 1 \\
\hline Management support (MS) & 0.395 & 31.1 & 2 \\
\hline External pressure (EP) & 0.245 & 19.3 & 3 \\
\hline External support (ES) & 0.187 & 14.7 & 4 \\
\hline
\end{tabular}

Source: Authors' own research 


\section{Discussion, implications and conclusion \\ Discussion}

The aim of the current study is to develop and test a theoretical model that investigates the determinants of E-commerce adoption of SMEs in the context of Vietnam. This leads to the emergence of two major findings, which are directly related to four abovementioned hypotheses concerning about the reality of technology acceptance.

The first findings consider the determinants of E-commerce adoption. Specifically, it can be inferred that the dependent variable is significantly impacted by four factors, namely in order: Technology perceived compatibility (TC); Management support (MS), External pressure (EP) and External support (ES). In particular, TC is considered to be the most important factor. Conceptually, TC relates to the level of readiness that an innovative technology should be implemented in an organization without violating existing organizational values, needs and past experiences of potential adopters (Kanchanatanee et al., 2014). In consistent with prior researches, E-commerce adoption is under considerable impact of TC and the incompatibility between E-commerce and business picture hinders company intention to accept new technology (Islam, 2016; Ozturk et al., 2016). Besides, management support from the organization plays an essential part in technological innovation process. The role of management is proven to be indispensable in business, especially in SMEs situation, the managerial decisions directly create better or worse performance. Managers may face obstacles in adopting the technology but the further efficiency would be seriously considered. Lastly, EP and ES produced normal effects on the adopters. SMEs are experiencing shortage of authorised support. Nevertheless, in other side, Government have not presented significant pressure onto SMEs and this creates opportunities for SMEs to develop.

The second findings from the research indicates that both external and internal factors have impacts on the E-commerce adoption of SMEs in Vietnam. However, the issues arising inside the companies influence more significantly. TC and MS possess above 35\% of influence and become the most important factors for the adopters to consider. In the meanwhile, EP and ES (external factors) are also the slight determinants with under $20 \%$ of influence. The exteriors play a noticeable role as the encouraging or discouraging sources of actions for the companies. As a consequence, if there are compulsory priorities, internal factors should be more favourable. Furthermore, the two categories of factors would contribute to the establishment of solid framework for technology acceptance model in SMEs. The adoption process should start from the inside of SMEs. Compatibility can be the first and foremost issue to be considered. When the TC is reasonable, MS follows. Internal expertise of SMEs can be considered as one of the main reasons in deciding whether to accept new technology. However, the process may encounter hindrance depending on the ability of the managers. If the managers can produce effective decision, the business would be innovative. The final considerations of the process are EP and ES which serve as encouraging and discouraging factors for technology acceptance in SMEs. Generally, E-commerce adoption can be affected by internal and external factors, however, the inside should be more emphasized. 


\section{Implications}

According to the major findings of the study, the four determinants contributing to the Ecommerce adoption suggest several implications for managers and researchers.

For managers, E-commerce adoption is considered to be important in the context of revolutionized business, especially for SMEs (Bakri and Katsioloudes, 2015). The Internet has emerged and changed the nature of economy; therefore, it is becoming compulsory for SMEs to implement technology acceptance with the purpose of maintaining profitable and competitive in the market. SMEs in Vietnam are not exceptional. With the number of adopters increased overtime, E-commerce rivalry is getting highly fierce. Moreover, technology could result in cost reduction and contribute to the overall efficiency which creates competitive advantages (Ibrahim et al., 2019). Consequently, it is beneficial to establish framework for E-commerce adoption particularly and technology acceptance generally in the context of Vietnam. The SME managers should be aware of the determinants, namely: Technology perceived compatibility (TC); Management support (MS), External pressure (EP) and External support (ES) and the emphasis should be on internal factors. The priority should be placed in the TC and MS according to the abovementioned. Another issue relating to managers is that the management support factor which represents the managerial skills, knowledge or understanding about E-commerce can influence the adoption process. Therefore, it would be recommended that managers may update the technological information constantly to keep up with the changing pace of the economy and deliver what customers desire. Scholars has pointed out that there is an inline relationship between managers' understanding about E-commerce and the successful performance of SMEs (Ghobakhloo and Tang, 2013; Mohtaramzadeh et al., 2017). Generally, SME managers may seriously consider the favourable strategy of implementing E-commerce adoption including: effectively invest in e-commerce, thoroughly train, drive staff or clients about the technologies and completely fulfil the process. More importantly, there must be total commitment on the E-commerce adoption in organizational level, top down from chief executive to normal staff.

For researchers, there are several different implications to be considered. The study is realized under the SMEs perspective and would produce biased questionnaire answers. This point of view may be limited to profit maximization and omit the other issues as ethics, trends or market influencers. However, the research questions which has been answered by the findings can be utilized to recommend innovative measurement and encouragement for SMEs in Vietnam to boost the E-commerce adoption process. Future research might base on the single point of view (SME perspective) to conduct study beyond the classical ones. Depending on the nature of business, there should be different approaches for E-commerce adoption process so that, the findings may vary. This requires a larger scope of research for establishing a systematic framework for technology acceptance of SMEs in Vietnam. Last but not least, the study is conducted immediately after the effects of COVID-19 pandemic in Vietnam leading to the fact that SMEs may be more volunteer to implement online retailing. Therefore, future researches should eliminate this temporary phenomenon by researching in the normal period, not affected by global threats as the deadly pandemic.

\section{Limitations}

Despite the author's effort, the study still encounters several limitations. Firstly, sample size needs to be larger. Due to the hindrance from COVID-19, the questionnaire was only 
delivered online, via Google drive and it reduces the number of participants (no direct interaction with participants). Social distancing and lockdowns also forced numerous businesses to be collapsed. This may directly or indirectly affect the overall findings. Besides, the scope of research is restricted to megacities, namely Hanoi, Ho Chi Minh City, Da Nang, Can Tho... (accounting for $97 \%$ of the participants). Therefore, the credibility may be not adequately solid because of the differences in E-commerce adoption among megacities and small cities. Another issue with the study may belong to the research model. There may be better model with more determinants and may produce contradicted results.

\section{Recommendation for further study}

The study "Towards an economic recovery after the COVID-19 pandemic: empirical study on electronic commerce adoption of small and medium enterprises in Vietnam" has some limitations due to COVID-19 pandemic effects and the shortage of time available. Therefore, in recommending for further study, the research scope should be widened. In this study, the buying routine is paid special attention on several mega cities such as Hanoi, Ho Chi Minh City, Da Nang, Can Tho...Consequently, there has not been thorough comparisons among those cities and other smaller cities in Vietnam. Moreover, the COVID-19 has come back and forth so that SMEs in Vietnam need to have long-term commitment or changes for dealing with the reality. The authors conducted the researches in the first years of emerging for the deadly pandemic and when the new wave of COVID-19 returned to Vietnam, the effects have changed dramatically. Therefore, it is urgent that further studies can take into account these changes in order to provide superior methods for minimizing the loss in SMEs business. Last but not least, it would be reasonable if further studies can base on this current result; then analyse, assert and give valuable comments on the effectiveness of the coping methods implemented in 2020 and 2021 for COVID-19. As such, there would be higher-efficiency procedures to prevent the Corona viruses to deepen the economy in the following years.

\section{Conclusion}

It cannot be denied that COVID-19 pandemic has created indispensable and negative consequences on the global economy. The handling process is being carried out in several countries; however, this would take longer time to finish. SMEs, with the worse financial power, has been more badly-affected by the pandemic so that the enterprises must not only count on economic support from Vietnam Government. It is suggested that adopting Ecommerce contribute as an effective method to increase sale revenue and function correctly even on the occasion of social distancing. As a result, SMEs in Vietnam must be encouraged to take actions in technology acceptance, raising the level of readiness to change from physical stores to online platforms.

Therefore, the study "Towards an economic recovery after the COVID-19pandemic: empirical study of electronic commerce adoption in small and medium sized enterprises" is implemented by analysing 229 Vietnamese SMEs to come up with major findings relating to the four important determinants of E-commerce adoption of SMEs in the context of Vietnam, namely: Technology perceived compatibility (TC); Management support (MS), External pressure (EP) and External support (ES). Thus, the resources of the SMEs should be allocated reasonably in both internal factors (compatibility and management) and external factors (pressure and support). Conclusively, the findings of the study are applicable in the SME 
environment of Vietnam in order to support and recover these companies during the severe time of COVID-19 pandemic.

\section{Acknowledgement}

This research is funded by Vietnam National Foundation for Science and Technology Development (NAFOSTED) under grant number 502.02-2018.306.

\section{References}

Abed, S. S. (2020). Social commerce adoption using TOE framework: An empirical investigation of Saudi Arabian SMEs. International Journal of Information Management, 53, 102-118.

Akpan, I. J., Udoh, E. A. P., \& Adebisi, B. (2020). Small business awareness and adoption of state-of-the-art technologies in emerging and developing markets, and lessons from the COVID-19 pandemic. Journal of Small Business \& Entrepreneurship, 1-18.

Bakri, A. A., \& Katsioloudes, M. I. (2015). The factors affecting e-commerce adoption by Jordanian SMEs. Management Research Review.

Chang, H. H., \& Meyerhoefer, C. D. (2020). COVID-19 and the Demand for Online Food Shopping Services: Empirical Evidence from Taiwan. American Journal of Agricultural Economics.

Chiu, C. Y., Chen, S., \& Chen, C. L. (2017). An integrated perspective of TOE framework and innovation diffusion in broadband mobile applications adoption by enterprises. International Journal of Management, Economics and Social Sciences (IJMESS), 6(1), 14-39.

Cohen, R. J., Smith, D. K., \& Swerdlik, M. E. (1992). Psychological testing and assessment.

Dannenberg, P., Fuchs, M., Riedler, T., \& Wiedemann, C. (2020). Digital transition by COVID-19 pandemic? The German food online retail. Journal of Economic and Human Geography, 111(3), 543-560.

Dima, A.M., Maassen, M.A. 2018). From waterfall to agile software: Development models in the IT sector, 2006 to 2018. impacts on company management. Journal of International Studies, 11 (2), pp. 315-326.

Dinca, V.M., Dima, A.M., Rozsa, Z. (2019). Determinants of Cloud Computing Adoption by Romanian SMEs in the Digital Economy. Journal of Business Economics and Management. 20 (4), 798-820.

Duan, X., Deng, H., \& Corbitt, B. (2012). Evaluating the critical determinants for adopting emarket in Australian small-and-medium sized enterprises. Management Research Review, 35.

Dubelaar, C., Sohal, A., \& Savic, V. (2005). Benefits, impediments and critical success factors in B2C E-business adoption. Technovation, 25(11), 1251-1262.

Farmaki, A., Miguel, C., Drotarova, M. H., Aleksic, A., Casni, A. C., \& Efthymiadou, F. (2020). Impacts of COVID-19on peer-to-peer accommodation platforms: Host perceptions and responses. International journal of hospitality management, 91, 102-663.

Gao, J., Zheng, P., Jia, Y., Chen, H., Mao, Y., Chen, S., \& Dai, J. (2020). Mental health problems and social media exposure during COVID-19 outbreak. Plos one, 15(4). 
Ghobakhloo, M., \& Tang, S. H. (2013). The role of owner/manager in adoption of electronic commerce in small businesses: The case of developing countries. Journal of small business and enterprise development.

Gourinchas, P. O. (2020). Flattening the pandemic and recession curves. Mitigating the COVID Economic Crisis: Act Fast and Do Whatever, 31, 57-62.

Gujarati, D, N. (2004). Basic Econometrics. 4th edition. McGraw - Hill Irwin.

Hair, J. F., Black, W. C., Babin, B. J., \& Anderson, R. E. (2013). Multivariate data analysis: Pearson new international edition. Pearson Higher Ed.

Hamad, H., Elbeltagi, I., \& El-Gohary, H. (2018). An empirical investigation of business-tobusiness e-commerce adoption and its impact on SMEs competitive advantage: The case of Egyptian manufacturing SMEs. Strategic Change, 27(3), 209-229.

Hameed, M. A., Counsell, S., \& Swift, S. (2012). A conceptual model for the process of IT innovation adoption in organizations.Journal of Engineering and Technology Management, 29(3), 358-390.

Hong, W., \& Zhu, K. (2006). Migrating to Internet-based e-commerce: Factors affecting ecommerce adoption and migration at the form level. Information \& Management, 41, $204-221$.

Hui, E. C., Zhang, P. H., \& Zheng, X. (2013). Facilities management service and customer satisfaction in shopping mall sector. Facilities, 31 (5), 194 - 207

Iacovou, C. L., Benbasat, I., \& Dexter, A. S. (1995). Electronic data interchange and small organizations: Adoption and Impact of Technology. MIS Quarterly, 465-485.

Jabri, I. A., \& Sohail, M. (2012). Mobile banking adoption: application of diffusion of innovation theory, Journal of Electronic Commerce Research, 13 (4).

Juergensen, J., Guimón, J., \& Narula, R. (2020). European SMEs amidst the COVID-19 crisis: assessing impact and policy responses. Journal of Industrial and Business Economics, 47(3), 499-510.

Kanchanatanee, K., Suwanno, N., \& Jarernvongrayab, A. (2014). Effects of attitude toward using, perceived usefulness, perceived ease of use and perceived compatibility on intention to use E-marketing. Journal of Management Research, 6(3), 1.

Kwilinski, A. (2019). Implementation of blockchain technology in accounting sphere. Academy of Accounting and Financial Studies Journal, 23, 1-6.

Mohtaramzadeh, M., Ramayah, T., \& Jun-Hwa, C. (2018). B2B e-commerce adoption in Iranian manufacturing companies: Analyzing the moderating role of organizational culture. International Journal of Human-Computer Interaction, 34(7), 621-639.

Morteza, G., Daniel, A., \& Jose, B.A. (2011). Adoption of e-commerce applications in SMEs. Industrial Management \& Data Systems, 111(8), 1238-1269.

Ocloo, C. E., Xuhua, H., Akaba, S., Addai, M., Worwui-Brown, D. K., \& Spio-Kwofie, A. (2018). B2B E-commerce Adoption amongst manufacturing SMEs: An Evidence from Ghana. Australian Journal of Economics and Management Sciences, 8(1).

Ozturk, A. B., Nusair, K., Okumus, F., \& Hua, N. (2016). The role of utilitarian and hedonic values on users' continued usage intention in a mobile hotel booking environment. International Journal of Hospitality Management, 57, 106-115.

Priyono, A., Moin, A., \& Putri, V. N. A. O. (2020). Identifying Digital Transformation Paths in the Business Model of SMEs during the COVID-19 Pandemic.Journal of Open Innovation: Technology, Market, and Complexity, 6(4), 104. 
Rahayu, R., \& Day, J. (2015). Determinant factors of e-commerce adoption by SMEs in developing country: evidence from Indonesia.Procedia-social and behavioral sciences, 195, 142-150.

Ramdani, B., Chevers, D., \& Williams, D. A. (2013). SMEs' adoption of enterprise applications: A technology-organisation-environment model. Journal of Small Business and Enterprise Development, 20(4), 735-753.

Requena, J. V, Sellens, J. T, Artola, A. M, \& Ardura, I. R (2007). An integrated model of the adoption and extent of e-commerce in firms. International Advances in Economic Research, 13(2), 222-241.

Rodgers, S., \& Harris, M. A. (2003). Gender and e-commerce: An exploratory study. Journal of advertising research, 43(3), 322-329.

Rowe, F., Truex, D., \& Huynh, M. Q. (2012). An empirical study of determinants of e-commerce adoption in SMEs in Vietnam: An economy in transition. Journal of Global Information Management (JGIM), 20(3), 23-54.

Scupola, A., Henten, A., \& Nicolajsen, H. W. (2009). E-services: Characteristics, scope and conceptual strengths. International Journal of E-Services and Mobile Applications (IJESMA), 1(3), 1-16.

Syriopoulos, K. (2020). The impact of COVID-19 on entrepreneurship and SMEs. Journal of the International Academy for Case Studies, 26(2), 1-2.

Teo, T. S. H. \& Tan, M. (2000). Factors influencing the adoption of internet banking. Journal of the Association for Information Systems, 1(5), 14 - 29

Thi, L. S. \& Lim, H. E. (2011). Estimating the determinants of B2B e-commerce adoption among small \& medium enterprises. International Journal of Business \& Society, 12(1).

Thong, J. Y. L. \& Yap, C. S. (1995). An integrated model of information systems adoption in small businesses. Journal of Management Information System, 15(4), 275-290.

Tiago, 0., \& Maria, F. M. (2010). Understanding e-business adoption across industries in European countries. Industrial Management \& Data Systems, 110(9), 1337-1354.

To, M. L., \& Ngai, E. W. (2006). Predicting the organisational adoption of B2C e-commerce: an empirical study. Industrial Management \& Data Systems.

World Health Organization. (2020). Coronavirus disease (COVID-19) pandemic. Accessed on December 18, 2020 at: https://www.who.int/emergencies/diseases/novelcoronavirus-2019.

Zhu, K., Dong, S., Xu, S.X., \& Kraemer, K.L. (2006). Innovation diffusion in global contexts: determinants of post-adoption digital transforma- tion of European companies. European journal of information systems, 15(6), 601-616.

Zhu, K., Kraemer, K. L., \& Xu, S. (2006). The process of innovation assimilation by firms in different countries: a technology diffusion perspective on e-business. Management science, 52(10), 1557-1576.

\section{Appendices}

\section{Questionnaire}

Part A: E-commerce adoption in small and medium sized enterprises

The following statements ask your thoughts about e-commerce adoption in your own company. Please choose the number that best match, how much you agree or disagree with each statement (Values range from 1 to 5, representing Strongly Disagree to Strongly Agree). 


\section{Organizational context}

\begin{tabular}{|c|c|c|c|c|c|c|}
\hline & & $\begin{array}{l}\text { Strongly } \\
\text { Disagree }\end{array}$ & Disagree & Neutral & Agree & $\begin{array}{l}\text { Strongly } \\
\text { Agree }\end{array}$ \\
\hline \multicolumn{7}{|l|}{ Organization employee (H1) } \\
\hline $\begin{array}{l}\text { 1.1 Employees are knowledgeable about E- } \\
\text { commerce }\end{array}$ & OE1 & & & & & \\
\hline $\begin{array}{l}\text { 1.2 Employees are competent about new } \\
\text { technology }\end{array}$ & OE2 & & & & & \\
\hline $\begin{array}{l}1.3 \text { Most of employees can use computer } \\
\text { proficiently }\end{array}$ & OE3 & & & & & \\
\hline \multicolumn{7}{|l|}{ Organizational readiness (H2) } \\
\hline $\begin{array}{l}1.4 \text { Organizational has good financial resources } \\
\text { to invest in E-commerce implication }\end{array}$ & OR4 & & & & & \\
\hline $\begin{array}{l}\text { 1.5 Organizational has good IT resources } \\
\text { (computer, telephone, devices...) to invest in E- } \\
\text { commerce implication }\end{array}$ & OR5 & & & & & \\
\hline $\begin{array}{l}\text { 1.6 Organization is aware of the role of E- } \\
\text { commerce in improving business after COVID- } 19 \\
\text { pandemic }\end{array}$ & OR6 & & & & & \\
\hline $\begin{array}{l}\text { 1.7 Organization has orient business strategy } \\
\text { towards E-commerce after COVID- } 19 \text { pandemic }\end{array}$ & OR7 & & & & & \\
\hline
\end{tabular}

\section{Technological context}

\begin{tabular}{|l|l|l|l|l|l|l|l|}
\hline & & $\begin{array}{l}\text { Strongly } \\
\text { Disagree }\end{array}$ & Disagree & Neutral & Agree & $\begin{array}{c}\text { Strongly } \\
\text { Agree }\end{array}$ \\
\hline \multicolumn{2}{|l|}{ Technology perceived benefits (H3) } & & & & & \\
\hline $\begin{array}{l}\text { 2.1 Ecommerce adoption improves customer } \\
\text { relationship during COVID-19 pandemic }\end{array}$ & TB1 & & & & & \\
\hline $\begin{array}{l}\text { 2.2 Ecommerce adoption broaden market or } \\
\text { market share during COVID-19 pandemic }\end{array}$ & TB2 & & & & & \\
\hline $\begin{array}{l}\text { 2.3 Ecommerce adoption increase business } \\
\text { revenue during COVID-19 pandemic }\end{array}$ & TB3 & & & & & \\
\hline Technology perceived compatibility (H4) & & & & & & \\
\hline $\begin{array}{l}\text { 2.4. Ecommerce adoption is suitable with } \\
\text { current objectives of company during COVID-19 } \\
\text { pandemic }\end{array}$ & TC4 & & & & & & \\
\hline
\end{tabular}




\begin{tabular}{|l|l|l|l|l|l|l|}
\hline $\begin{array}{l}2.5 \text { Ecommerce adoption is compatible with } \\
\text { customer's behaviour during Covid-19 }\end{array}$ & TC5 & & & & & \\
\hline $\begin{array}{l}\text { 2.6 Ecommerce adoption is compatible with } \\
\text { experience of other companies in the same } \\
\text { sector during Covid-19 }\end{array}$ & TC6 & & & & & \\
\hline
\end{tabular}

\section{Environmental context}

\begin{tabular}{|c|c|c|c|c|c|c|}
\hline & & $\begin{array}{l}\text { Strongly } \\
\text { Disagree }\end{array}$ & Disagree & Neutral & Agree & $\begin{array}{l}\text { Strongly } \\
\text { Agree }\end{array}$ \\
\hline \multicolumn{7}{|l|}{ External pressure (H5) } \\
\hline $\begin{array}{l}3.1 \text { There is a great competitiveness in E- } \\
\text { commerce sector during and after COVID-19 } \\
\text { pandemic }\end{array}$ & EP1 & & & & & \\
\hline $\begin{array}{l}3.2 \text { Vietnamese customers requires a better } \\
\text { quality of transaction platform }\end{array}$ & EP2 & & & & & \\
\hline $\begin{array}{l}3.3 \text { COVID- } 19 \text { pandemic leads to the raise of E- } \\
\text { commerce adoption in almost enterprises }\end{array}$ & EP3 & & & & & \\
\hline \multicolumn{7}{|l|}{ External support (H6) } \\
\hline $\begin{array}{l}\text { 3.4 Company receives a financial support from } \\
\text { Government during and after COVID-19 } \\
\text { pandemic }\end{array}$ & ES4 & & & & & \\
\hline $\begin{array}{l}\text { 3.5 Company receives experiential support from } \\
\text { business community during and after COVID- } 19 \\
\text { pandemic }\end{array}$ & ES5 & & & & & \\
\hline $\begin{array}{l}\text { 3.6 Company is located in an area with a high } \\
\text { speed of E-commerce development }\end{array}$ & ES6 & & & & & \\
\hline
\end{tabular}

\section{Management support (H7)}

\begin{tabular}{|l|l|l|l|l|l|l|}
\hline & & $\begin{array}{c}\text { Strongly } \\
\text { Disagree }\end{array}$ & Disagree & Neutral & Agree & $\begin{array}{c}\text { Strongly } \\
\text { Agree }\end{array}$ \\
\hline $\begin{array}{l}\text { 4.1 Managers having a full awareness towards } \\
\text { technology results in accepting E-commerce } \\
\text { during COVID-19 pandemic }\end{array}$ & MS1 & & & & & \\
\hline $\begin{array}{l}\text { 4.2 Managers having a positive attitude towards } \\
\text { technology results in E-commerce adoption } \\
\text { during COVID-19 pandemic }\end{array}$ & MS2 & & & & & \\
\hline
\end{tabular}


4.3 A capable manager results in accepting Ecommerce during COVID-19 pandemic

MS3

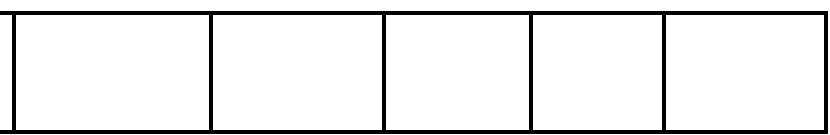

5. How likely is the E-commerce adoption in your enterprises?

\begin{tabular}{|l|l|l|l|l|l|l|}
\hline & & $\begin{array}{c}\text { Strongly } \\
\text { Disagree }\end{array}$ & Disagree & Neutral & Agree & $\begin{array}{c}\text { Strongly } \\
\text { Agree }\end{array}$ \\
\hline $\begin{array}{l}\text { 5.1 My enterprise is considering to adopt E- } \\
\text { commerce during Covid-19 }\end{array}$ & EA1 & & & & & \\
\hline $\begin{array}{l}\text { 5.2 My enterprise certainly adopts E-commerce } \\
\text { during Covid-19 }\end{array}$ & EA2 & & & & & \\
\hline $\begin{array}{l}\text { 5.3. My enterprise tends to adopt E-commerce in } \\
\text { the future }\end{array}$ & EA3 & & & & & \\
\hline
\end{tabular}

Part B: Demographic Questions

\begin{tabular}{|c|c|}
\hline $\begin{array}{l}\text { 6. What is your gender? } \\
\text { - Female } \\
\text { - Male } \\
\text { - Prefer not to say }\end{array}$ & $\begin{array}{l}\text { 9. What is your education level? } \\
\text { - } \text { Bachelor } \\
\text { - } \text { Master } \\
\text { - } \text { Doctor } \\
\end{array}$ \\
\hline 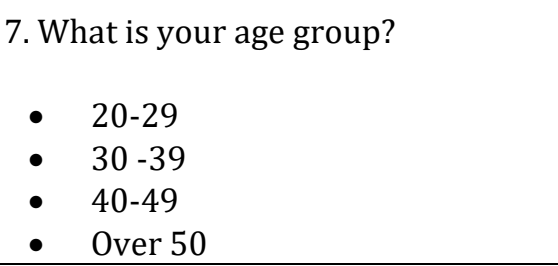 & $\begin{array}{l}\text { 10. Which type of service that you are working? } \\
\text { - Manufacturing } \\
\text { - } \quad \text { Retail/wholesale } \\
\text { Other }\end{array}$ \\
\hline $\begin{array}{l}\text { 8. What is your current job position? } \\
\text { - Staff } \\
\text { - Team leader } \\
\text { - Manager }\end{array}$ & $\begin{array}{l}\text { 11. How long does you enterprise adopt E-commerce? } \\
\text { - About } 1 \text { years } \\
\text { - About 2-3 years } \\
\text { - Over } 3 \text { years }\end{array}$ \\
\hline $\begin{array}{l}\text { 9. What is your education level? } \\
\text { - Bachelor } \\
\text { - Master } \\
\text { - } \text { Doctor } \\
\text { - Other }\end{array}$ & $\begin{array}{l}\text { 12. Which location is your enterprise in? } \\
\text { - Mega cities (Hanoi, Ho Chi Minh, Da Nang, Hai } \\
\text { Phong, Can Tho) } \\
\text { - Other cities }\end{array}$ \\
\hline
\end{tabular}

\section{The result of reliability test}

\begin{tabular}{|l|l|l|l|}
\hline & Mean & \multicolumn{1}{|c|}{$\begin{array}{c}\text { Cronbach's } \\
\text { Alpha }\end{array}$} & $\begin{array}{c}\text { Corrected } \\
\text { Items - Total } \\
\text { correlation }\end{array}$ \\
\hline OE - Organizational employee & $\mathbf{3 . 8 0}$ & $\mathbf{0 . 8 2 4}$ & \\
\hline OE1- Employees are knowledgeable about E-commerce & 3.76 & 0.708 & 0.727 \\
\hline OE2- Employees are competent about new technology & 3.75 & 0.735 & 0.707 \\
\hline OE3- Most of employees can use computer proficiently & 3.90 & 0.779 & 0.614 \\
\hline
\end{tabular}




\begin{tabular}{|c|c|c|c|}
\hline OR - Organizational readiness & 3.75 & 0.813 & \\
\hline $\begin{array}{l}\text { OR4- Organizational has good financial resources to invest } \\
\text { in E-commerce implication }\end{array}$ & 3.61 & 0.701 & 0.755 \\
\hline $\begin{array}{l}\text { OR5- Organizational has good IT resources (computer, } \\
\text { telephone, devices...) to invest in E-commerce implication }\end{array}$ & 3.74 & 0.797 & 0.568 \\
\hline $\begin{array}{l}\text { OR6- Organization is aware of the role of E-commerce in } \\
\text { improving business after COVID-19pandemic }\end{array}$ & 3.92 & 0.742 & 0.688 \\
\hline $\begin{array}{l}\text { OR7- Organization has orient business strategy towards E- } \\
\text { commerce after COVID-19pandemic }\end{array}$ & 3.76 & 0.804 & 0.543 \\
\hline TB - Technology perceived benefits & 3.78 & 0.892 & \\
\hline $\begin{array}{l}\text { TB1- Ecommerce adoption improves customer relationship } \\
\text { during COVID-19pandemic }\end{array}$ & 3.82 & 0.870 & 0.760 \\
\hline $\begin{array}{l}\text { TB2- Ecommerce adoption broaden market or market share } \\
\text { during COVID-19pandemic }\end{array}$ & 3.90 & 0.812 & 0.829 \\
\hline $\begin{array}{l}\text { TB3- Ecommerce adoption increase business revenue } \\
\text { during COVID-19pandemic }\end{array}$ & 3.64 & 0.851 & 0.790 \\
\hline TC - Technology perceived compatibility & 3.81 & 0.875 & \\
\hline $\begin{array}{l}\text { TC4- Ecommerce adoption is suitable with current } \\
\text { objectives of company during COVID-19pandemic }\end{array}$ & 3.78 & 0.764 & 0.82 \\
\hline $\begin{array}{l}\text { TC5- Ecommerce adoption is compatible with customer's } \\
\text { behaviour during Covid-19 }\end{array}$ & 4.07 & 0.864 & 0.68 \\
\hline $\begin{array}{l}\text { TC6- Ecommerce adoption is compatible with experience of } \\
\text { other companies in the same sector during Covid-19 }\end{array}$ & 3.60 & 0.793 & 0.79 \\
\hline EP - External pressure & 4.05 & 0.828 & \\
\hline $\begin{array}{l}\text { EP1- There is a great competitiveness in E-commerce sector } \\
\text { during and after COVID-19pandemic }\end{array}$ & 3.86 & 0.790 & 0.669 \\
\hline $\begin{array}{l}\text { EP2- Vietnamese customers requires a better quality of } \\
\text { transaction platform }\end{array}$ & 4.28 & 0.771 & 0.691 \\
\hline $\begin{array}{l}\text { EP3- COVID-19 pandemic leads to the raise of E-commerce } \\
\text { adoption in almost enterprises }\end{array}$ & 4.02 & 0.726 & 0.721 \\
\hline ES - External support & 3.36 & 0.806 & \\
\hline $\begin{array}{l}\text { ES4- Company receives a financial support from } \\
\text { Government during and after COVID-19pandemic }\end{array}$ & 3.24 & 0.737 & 0.654 \\
\hline $\begin{array}{l}\text { ES5- Company receives experiential support from business } \\
\text { community during and after COVID-19pandemic }\end{array}$ & 3.31 & 0.732 & 0.658 \\
\hline $\begin{array}{l}\text { ES6- Company is located in an area with a high speed of E- } \\
\text { commerce development }\end{array}$ & 3.56 & 0.734 & 0.671 \\
\hline MS - Management support & 3.85 & 0.880 & \\
\hline $\begin{array}{l}\text { MS1- Managers having a full awareness towards technology } \\
\text { results in accepting E-commerce during COVID-19pandemic }\end{array}$ & 3.83 & 0.831 & 0.768 \\
\hline $\begin{array}{l}\text { MS2- Managers having a positive attitude towards } \\
\text { technology results in E-commerce adoption during COVID- } \\
\text { 19pandemic }\end{array}$ & 3.92 & 0.843 & 0.756 \\
\hline $\begin{array}{l}\text { MS3- A capable manager results in accepting E-commerce } \\
\text { during COVID-19pandemic }\end{array}$ & 3.82 & 0.818 & 0.782 \\
\hline EA - E-commerce adoption & 3.62 & 0.753 & \\
\hline $\begin{array}{l}\text { EA1- My enterprise is considering to adopt E-commerce } \\
\text { during Covid-19 }\end{array}$ & 3.61 & 0.704 & 0.530 \\
\hline $\begin{array}{l}\text { EA2- My enterprise certainly adopts E-commerce during } \\
\text { Covid-19 }\end{array}$ & 3.69 & 0.750 & 0.500 \\
\hline EA3- My enterprise tends to adopt E-commerce in the future & 3.58 & 0.705 & 0.552 \\
\hline
\end{tabular}

